\title{
Differential sensitivity of locally naturalized Panicum species to HPPD- and ALS-inhibiting herbicides
}

Benny De Cauwer*, Tim Geeroms, Sofie Claerhout, Robert Bulcke \& Dirk Reheul

Weed Science Unit, Department of Plant Production, Faculty of Bioscience Engineering, Ghent University, Coupure Links 653 , 9000 Gent, Belgium

* Corresponding author: Benny.decauwer@ugent.be

Received 21 August 2013, accepted 09 January 2014

\begin{abstract}
Panicum schinzii (Transvaal millet), P. dichotomiflorum (Fall panicum) and $P$. capillare (Witchgrass) are alien panicoid grasses that have gradually spread and are now locally naturalized in corn fields in Belgium. One of the possible reasons for their expansion in corn fields might be a lower sensitivity to post-emergence herbicides acting against panicoid grasses, in particular those inhibiting 4-hydroxyphenyl pyruvate dioxygenase (HPPD) and acetolactate synthase (ALS). Dose-response pot experiments were conducted in the greenhouse to evaluate the effectiveness of five HPPD-inhibiting herbicides (sulcotrione, mesotrione, isoxaflutole, topramezone, tembotrione) and two ALS-inhibiting herbicides (nicosulfuron, foramsulfuron) for controlling populations of $P$. schinzii, $P$. dichotomiflorum and $P$. capillare (all naturalized Belgian populations except for $P$. capillare). In another dose-response pot experiment, sensitivity of five local $P$. dichotomiflorum populations to HPPD-inhibitors and nicosulfuron was investigated. Finally, the influence of growth stage at time of herbicide application on efficacy of topramezone and nicosulfuron for Panicum control was evaluated. Large interspecific differences in sensitivity to HPPD-inhibiting herbicides were observed. Panicum schinzii was sensitive to tembotrione but moderately sensitive to topramezone and poorly sensitive to mesotrione and sulcotrione. However, $P$. dichotomiflorum was sensitive to mesotrione and topramezone but moderately sensitive to tembotrione. All Panicum species were sensitive to low doses of nicosulfuron and foramsulfuron. Naturalized P. dichotomiflorum populations exhibited differential herbicide sensitivity profiles. All species tested showed a progressive decrease in sensitivity to topramezone and nicosulfuron with seedling age. A satisfactory post-emergence control of Panicum species in the field will require appropriate choice of herbicide and dose, as well as a more timely application (i.e. before weeds reach the four leaves stage).
\end{abstract}

Key words: Growth stage, herbicide sensitivity, panicoid grasses, sulfonylurea herbicides, triketone herbicides

\section{Introduction}

The rapid increase of corn (Zea mays) cultivation in Flanders (Belgium) that started ca. four decades ago created op- timal conditions for the establishment of self-perpetuating populations of many panicoid weed grasses (e.g. Panicum spp., Echinochloa spp., Setaria spp., Digitaria spp.) in and around corn fields (Vanderhoeven et al. 2006). Although the toolbox for weed control in corn contains an impressive variety of herbicides with different molecular modes of action (Santel 2009), newly introduced and naturalizing panicoid grasses continuously complicate appropriate choice of herbicides and their dosages.

Until recently the Panicum species $P$. schinzii (Transvaal millet or Land grass, native to South Africa), P. dichotomiflorum (Fall panicum, native to North and South America) and P. capillare (Witchgrass, native to North America) were completely overlooked in Belgium. Since 1970, these species have gradually spread and are now locally naturalized and abundant in and along corn fields, particularly on sandy soils (Hoste \& Verloove 2001, Verloove 2001, Van Landuyt et al. 2006). Less than $3 \%$ of their populations are found outside corn fields (Vanderhoeven et al. 2006). Another Panicum species sporadically found in corn fields is $P$. miliaceum subsp. miliaceum (Proso millet, native to central Asia) but this subspecies rarely persists because of the retention of the florets on the plant and poor seed survival over winter (Freckmann \& Lelong 2003).

Panicum dichotomiflorum and P. schinzii are morphologically hard to distinguish, particularly at early growth stages. Correct identification requires a careful study of the lower florets with the aid of a hand lens. The lower florets of $P$. schinzii are staminate whereas in $P$. dichotomiflorum the lower florets are neuter (Van Der Meijden 2005). Moreover, $P$. schinzii has blunter spikelets. One of the possible reasons for its expansion into corn fields, besides e.g. the lack of crop rotation (Vanderhoeven et al. 2006), might be a lower sensitivity to post-emergence (POST) corn herbicides used to control panicoid grasses, in particular 4-hydroxyphenyl pyruvate dioxygenase (HPPD)-inhibiting herbicides and acetolactate synthase (ALS)-inhibiting sulfonylureas.

Abovementioned Panicum species are highly competitive and prolific weeds in cereal grains and need to be controlled soon after emergence to prevent yield loss (Baker \& Terry 1991, Clements et al. 2004). Indeed, despite being relatively late emerging species, they grow fast and tiller profusely (Vengris \& Damon 1976). Panicum dichotomiflorum is one of the most important grassy weeds in American and Asian corn and sorghum (Sorghum bicolor) fields. According to Benson (1982) a season-long competition by $P$. dichotomi- 
florum at a density of $12-20$ plants $\mathrm{m}^{-2}$ reduced corn grain yield by 15 to $77 \%$. Panicum schinzii is a major weed in tropical cereals in Africa (Gibbs-Russell et al. 1990). Wax et al. (1981) listed P. capillare as one of the seven most common annual grasses found in North American corn and soybean fields. In small grain crops, $P$. capillare was among the three most common summer annual grass weeds in Nebraska where $P$. capillare and Echinochloa crus-galli were the most difficult to control (Wicks et al. 1995). Unfortunately, the actual impact of $P$. schinzii and $P$. capillare infestations on crop yield is not well documented.

Recently, in Belgium there have been many complaints about unsatisfactory Panicum control in corn. Unfortunately, in sharp contrast to other naturalized panicoid grasses belonging to the genera Echinochloa, Setaria and Digitaria, scientific literature detailing the herbicide sensitivity is lacking for abovementioned naturalized Panicum species. Therefore, in the present study the following research questions were addressed: (1) Do $P$. capillare, $P$. dichotomiflorum and $P$. schinzii show a difference in sensitivity to corn herbicides acting against panicoid grasses, in particular HPPD- and ALS-inhibitors? (2) Do locally naturalized $P$. dichotomiflorum populations vary in herbicide sensitivity? (3) What is the optimal growth stage for Panicum control?

\section{Materials and methods}

\section{Experiments}

During the summer of 2011, three dose-response pot experiments were conducted in the greenhouse. In experiment 1 , the effectiveness of five foliar-applied HPPD-inhibiting herbicides [topramezone (ARIETTA ${ }^{\circledR}$ ), mesotrione (CALLISTO ${ }^{\circledR}$ ), tembotrione (LAUDIS ${ }^{\circledast}$ ), sulcotrione $\left(\mathrm{MIKADO}^{\circledR}\right.$ ), isoxaflutole (Experimental product)] and two ALS-inhibiting herbicides [nicosulfuron $\left(\mathrm{KELVIN}^{\circledR}\right.$ ), foramsulfuron (EQUIP ${ }^{\circledR}$ )] for controlling populations of $P$. capillare, $P$. dichotomiflorum and $P$. schinzii was evaluated. Selected $P$. capillare population was 'Herbiseed' (a well-known reference population purchased from the seed company Herbiseed, Twyford, UK). Reference populations of $P$. dichotomiflorum and $P$. schinzii were not available and therefore we used locally naturalized populations from Belgian corn fields, namely 'Bellem' and 'Ursel', respectively. Although abovementioned HPPD-inhibitors are solely applied post-emergence in Belgian corn fields, except for isoxaflutole $\left(\mathrm{MERLIN}^{\circledR}\right)$ which is only applied pre-emergence to avoid crop injury, they also have residual soil activity (Bulcke et al. 1996, Rouchaud et al. 2000, Schönhammer et al. 2006, Schulte \& Köcher 2009). For this reason, experiment 1 was also designed to investigate the relative contribution from soil activity to weed control resulting from post-emergence applications of HPPDand ALS inhibitor herbicides. For this purpose, half of all pots were covered with a herbicide adsorbing film $(1 \mathrm{~mm})$ of activated charcoal (Aktivkole, Roth, Karlsruhe, Germany) shortly after sowing. The charcoal-treated pots were used to evaluate foliar activity of the applied herbicides, whereas pots without charcoal were used to evaluate total activity. Experiment 2 was designed to evaluate the importance of intraspecific variability in herbicide sensitivity. Since $P$. dichotomiflorum is the most widespread species amongst naturalized Panicum species, in Belgium (Van Landuyt et al. 2006), experiment 2 was focused on $P$. dichotomiflorum. Five local $P$. dichotomiflorum populations (Belgian populations 'Bellem', 'Adegem', 'Lembeke', 'Ursel' and 'Damme'), located at least $14 \mathrm{~km}$ apart, were screened for their sensitivity to four HPPD-inhibitors (mesotrione, tembotrione, sulcotrione and topramezone) and one ALS-inhibitor (nicosulfuron). Seeds of these populations were each collected in 2010 on at least 50 plants scattered over the whole corn field. In experiment 3 , the relation between weed growth stage and herbicide sensitivity was investigated by subjecting $P$. capillare, $P$. dichotomiflorum and $P$. schinzii plants, differing in growth stage, to foliar-applied topramezone and nicosulfuron. Topramezone was selected since it is a frequently and widely applied HPPD-inhibitor in corn in Flanders. Nicosulfuron is the most important ALS-inhibitor in corn. The same populations as in experiment 1 were used.

\section{Experimental setup}

All dose-response experiments were conducted in greenhouses using plastic pots filled with steamed sandy loam soil containing $2.2 \%$ organic matter, $51.6 \%$ silt $(2-50 \mu \mathrm{m})$, $39.9 \%$ sand $(>50 \mu \mathrm{m})$ and $8.6 \%$ clay with a $\mathrm{pH}-\mathrm{KCl}$ of 5.7 . The greenhouse was a rain-shelter plastic greenhouse, with sides left open up to $1 \mathrm{~m}$ high for natural ventilation. Daytime and nighttime mean temperature and humidity values, and mean light intensity during the experimental periods are given in Table 1.

Table 1: Daytime and nighttime mean temperature, relative humidity and mean daytime light intensity during the bioassay pot experiments

\begin{tabular}{|c|c|c|c|c|}
\hline & Experimental period & $\begin{array}{c}\text { Daytime/nighttime } \\
\text { mean temperature } \\
{ }^{\circ} \mathrm{C}\end{array}$ & $\begin{array}{c}\text { Daytime/nighttime } \\
\text { mean humidity } \\
\%\end{array}$ & $\begin{array}{c}\text { Mean daytime } \\
\text { light intensity } \\
\text { lux }\end{array}$ \\
\hline Experiment 1 & $11 / 07 / 2011-23 / 08 / 2011$ & $23 / 16$ & $70 / 90$ & 7030 \\
\hline Experiment 2 & 24/08/2011-03/10/2011 & $23 / 14$ & $66 / 90$ & 7555 \\
\hline Experiment 3 & 28/06/2011-09/08/2011 & $23 / 16$ & $64 / 84$ & 5055 \\
\hline
\end{tabular}


In all experiments, pots were seeded with 25 seeds per pot at $2 \mathrm{~mm}$ depth. As soon as seedlings had one fully developed true leaf (BBCH stage 11), they were thinned to five uniform plants per pot. Pots were irrigated by overhead sprinklers as needed. The experimental design was always a randomized block with three replicates. The experimental unit was one pot of five seedlings. All herbicides were applied with TeeJet XR11002 flat fan nozzles (TeeJet Technologies, Wheaton, USA) at a spray pressure of $180 \mathrm{kPa}$ and a spray volume of $3001 \mathrm{ha}^{-1}$. Each herbicide was tested in eight doses and compared to a control as enumerated in Table 2. According to preliminary experiments, dose ranges mentioned in Table 2 were optimal for the construction of dose-response curves. In experiment 1 and 2, herbicides were applied in the three (for $P$. dichotomiflorum and $P$. capillare) to four (for P. schinzii) true leaves stage. The four true leaves stage is the stage at which POST herbicides are most commonly applied in Flemish corn fields. In experiment 3, topramezone and nicosulfuron were applied at four different weed growth stages: BBCH11, one true leaf; BBCH12, two true leaves, BBCH13, three true leaves; $\mathrm{BBCH} 14$, four true leaves. These weed growth stages were achieved by staggered sowing times.

\section{Measurements}

In all bioassay experiments, foliage fresh biomass was harvested (clipped at the soil surface) and weighed 20 days after treatment (DAT).

\section{Data analysis}

Data obtained from single POST bioassays were analyzed with the Open Source language and environment $\mathrm{R}$ (version R2.11.1; R Development Core Team 2010) and its doseresponse curves extension package drc (Ritz \& Streibig 2005) based on Knezevic et al. (2007). The block effect of foliage fresh biomass was checked by analysis of variance and was in all instances non-significant. Hence, data from the three blocks were pooled before analysis.

Within experiments 1 and 2, dose-response curves for all Panicum populations were fitted simultaneously for each tested herbicide. Within experiment 3, dose-response curves for all growth stages of a particular Panicum population were fitted simultaneously for each tested herbicide. The initial regression model was the log-logistic model with four parameters (Streibig et al. 1993):

$$
\mathrm{Y}=c+\frac{d-c}{1+\exp [b(\log X-\log e)]}
$$

where Y represents biomass, i.e. foliar fresh weight per pot (g), at herbicide dose $x$. The dose required for $50 \%$ biomass reduction is given by $e$, also referred to as the $\mathrm{ED}_{50}\left(\mathrm{~g} \mathrm{ha}^{-1}\right)$. The parameter $b$ denotes the relative slope around this value and the upper and lower limit of the curve are $d$ and $c$ respectively. For all herbicides tested in experiment 1, except tembotrione and nicosulfuron, a likelihood ratio test indicated that the initial model could be reduced to the three parameter log-logistic model, with $c$ being zero. A Box-Cox transformation was applied on the data of meso-

Table 2: Herbicides and their doses examined in post-emergence (POST) dose-response bioassays

\begin{tabular}{|c|c|}
\hline Herbicide (formulated product) & Herbicide dose \\
\hline HPPD-inhibitors (HRAC group F2) & g ai ha-1 \\
\hline Isoxaflutole ${ }^{1}$ & $0-3.125-6.25-12.5-25-50-100-200-400$ \\
\hline \multicolumn{2}{|l|}{ 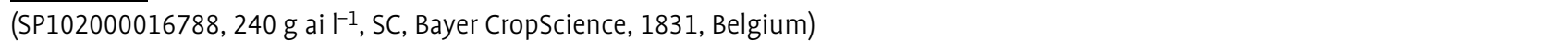 } \\
\hline Mesotrione & $0-2.5-5-10-20-40-80-160-320$ \\
\hline \multicolumn{2}{|l|}{ (Callisto, $100 \mathrm{~g}$ ai I-1, SC, Syngenta Crop protection, 7180 Seneffe, Belgium) } \\
\hline Sulcotrione & $0-15-30-60-120-240-480-960-1920$ \\
\hline \multicolumn{2}{|l|}{ 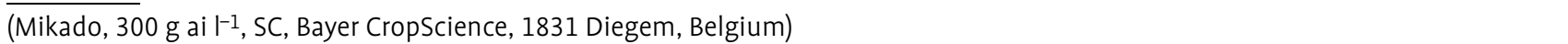 } \\
\hline Tembotrione $^{2}$ & $0-2.75-5.5-11-22-44-88-176-352$ \\
\hline \multicolumn{2}{|l|}{$\overline{\text { (Laudis, } 44 \mathrm{~g}}$ ai I-1, OD, Bayer CropScience, 1831 Diegem, Belgium) } \\
\hline Topramezone $^{3}$ & $0-1.6-3.2-6.3-12.6-25.2-50.4-100.8-201.6$ \\
\hline \multicolumn{2}{|l|}{ (Arietta, $336 \mathrm{~g}$ ai I-1 $^{-1}$, SC, Basf Belgium, 1170 Brussel, Belgium) } \\
\hline \multicolumn{2}{|l|}{ ALS-inhibitors (HRAC-group B) } \\
\hline Foramsulfuron $^{4}$ & $0-1.875-3.75-7.5-15-30-60-120-240$ \\
\hline \multicolumn{2}{|l|}{ 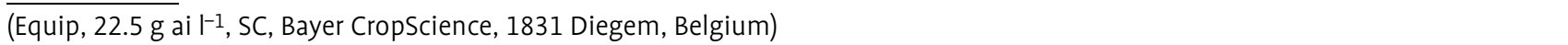 } \\
\hline Nicosulfuron & $0-0.63-1.25-2.5-5-10-20-40-80$ \\
\hline 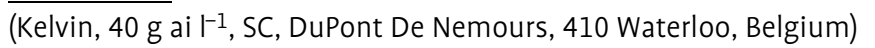 & \\
\hline
\end{tabular}

1 The experimental product combines isoxaflutole and the safener cyprosulfamide (1:1 ratio).

2 Laudis combines tembotrione and the safener isoxadifen-ethyl (2:1 ratio) with an adjuvant system in an oil dispersion (OD) formulation. ${ }^{3} 1 \mathrm{l} \mathrm{ha}^{-1}$ triglyceride oil (Actirob B, $812 \mathrm{~g}$ ai l-1, EC, Novance, F-60206 Compiegne, France), a methylated seed oil, was added to the herbicide spray solution to enhance foliar uptake and distribution within the shoot.

4 Equip combines foramsulfuron and the safener isoxadifen-ethyl (1:1 ratio). 
trione to obtain variance homogeneity (Streibig et al. 1993). For tembotrione and nicosulfuron, the four parameter Weibull model was used (Streibig et al. 1993):

$\mathrm{Y}=c+(\mathrm{d}-\mathrm{c}) \exp \{-\exp [b(\log X-\mathrm{e})]\}$

For biomass data of distinct $P$. dichotomiflorum populations (Experiment 2), the three parameter log-logistic model was used except for the response to mesotrione and topramezone, for which the initial four-parameter Weibull model could be reduced to the three parameter Weibull model, with $c$ being zero. The four parameter log-logistic model was used in experiment 3 , for biomass data of Panicum species treated with topramezone. Data of $P$. capillare were Box-Cox transformed to obtain variance homogeneity. For the response to nicosulfuron the three parameter loglogistic model was used except for the response of $P$. schinzii for which the four parameter log-logistic model could not be reduced.

Effective dosages (ED) and selectivity indices (SI) are commonly used to compare different dose-response curves. Effective dosage $\mathrm{ED}_{90}$ (dose required for $90 \%$ biomass reduction) and selectivity indices (SI) as relative potencies between two dose-response curves were derived from the regression model utilizing the delta method (Van der Vaart 1998). $\mathrm{SI}_{90}$ (i.e. the ratio between $E D_{90}$ for one dose response curve and $\mathrm{ED}_{90}$ for another dose-response curve) and $\mathrm{SI}_{50}$ (i.e. the ratio between $\mathrm{ED}_{50}$ for one dose-response curve and $\mathrm{ED}_{50}$ for another dose-response curve) were used to compare the relative differences of $\mathrm{ED}_{90}$ and $\mathrm{ED}_{50}$ among curves, respectively.

\section{Results and discussion}

\section{Experiment 1}

Large interspecific differences in sensitivity to HPPD-inhibiting herbicides were observed (Table 3). Panicum schinzii was sensitive (i.e., required a dose lower than the maximum authorized field dose to achieve $90 \%$ reduction in biomass) to tembotrione but moderately sensitive (i.e. required maximum field dose) to topramezone and poorly sensitive (i.e. required three-fold higher dose than maximum field dose) to mesotrione and sulcotrione. However, P. dichotomiflorum, a species that morphologically closely resembles P. schinzii, was sensitive to mesotrione (ED90 of $60.9 \mathrm{~g} \mathrm{ha}^{-1}$ ) and topramezone (ED90 of $7.5 \mathrm{~g} \mathrm{ha}^{-1}$ ) but moderately sensitive to tembotrione. However, according to Soltani et al. (2012), mesotrione at $150 \mathrm{~g} \mathrm{ha}^{-1}$ and topramezone at $12.5 \mathrm{~g} \mathrm{ha}^{-1}$, both with oil concentrate at $1.25 \% \mathrm{v} / \mathrm{v}$, provided moderate control (70-77\% biomass reduction) of $2-3$ leaf stage seedlings of $P$. dichotomiflorum. Panicum capillare was sensitive to sulcotrione and topramezone, moderately sensitive to tembotrione and poorly sensitive to mesotrione. Similarly, in the study of Soltani et al. (2012), 2-3 leaf stage seedlings of $P$. capillare were adequately controlled (>90\% biomass reduction) by topramezone but not by mesotrione. Panicum capillare and $P$. schinzii were poorly sensitive to foliar-applied isoxaflutole: doses two- to three-fold higher than maximum field dose (i.e. $75 \mathrm{~g}$ isoxaflutole ha ${ }^{-1}$ for pre-emergence commercial corn herbicide Merlin which contains 75\% isoxaflutole, without safener) were required for $90 \%$ control.

Table 3: $\mathrm{ED}_{50}$ and $\mathrm{ED}_{90}$ responses with standard errors of $P$. dichotomiflorum, P. capillare and $P$. schinzii to post-emergence HPPD- and ALS-inhibitors applied at the three to four true leaves stage (Experiment 1)

\begin{tabular}{|c|c|c|c|c|c|}
\hline \multirow[t]{2}{*}{ Herbicide } & \multirow[t]{2}{*}{$\begin{array}{l}\text { Effective } \\
\text { Dose }\end{array}$} & P. dichotomiflorum & P. capillare & P. schinzii & \multirow[t]{2}{*}{$\begin{array}{c}\text { Max. field dose } \\
\text { in Belgium }\end{array}$} \\
\hline & & & g ai & & \\
\hline \multicolumn{6}{|l|}{ HPPD-inhibitors } \\
\hline \multirow[t]{2}{*}{ Isoxaflutole } & $\mathrm{ED}_{50}$ & & $38.1 \pm 9.32 \mathrm{a}$ & $86.2 \pm 15.97 b$ & \\
\hline & $E D_{90}$ & & $231.2 \pm 84.68 a$ & $2450.5 \pm 993.73 b$ & \\
\hline \multirow[t]{2}{*}{ Mesotrione } & $\mathrm{ED}_{50}$ & $21.5 \pm 7.44 a$ & $80.9 \pm 22.36 b$ & $101.3 \pm 14.36 \mathrm{~b}$ & 150 \\
\hline & $\mathrm{ED}_{90}$ & $60.9 \pm 39.18 a$ & $492.0 \pm 237.86 b$ & $479.8 \pm 138.71 b$ & \\
\hline \multirow[t]{2}{*}{ Sulcotrione } & $\mathrm{ED}_{50}$ & & $64.4 \pm 16.79 a$ & $121.3 \pm 15.70 b$ & 450 \\
\hline & $\mathrm{ED}_{90}$ & & $278.3 \pm 126.09 a$ & $1043.6 \pm 217.59 b$ & \\
\hline \multirow[t]{2}{*}{ Tembotrione } & $\mathrm{ED}_{50}$ & $16.1 \pm 6.62 \mathrm{a}$ & $71.5 \pm 10.46 b$ & $19.3 \pm 0.94 a$ & 99 \\
\hline & $\mathrm{ED}_{90}$ & $66.0 \pm 43.14 a b$ & $125.6 \pm 34.18 b$ & $26.2 \pm 1.65 a$ & \\
\hline \multirow[t]{2}{*}{ Topramezone } & $\mathrm{ED}_{50}$ & $2.4 \pm 0.74 a$ & $2.5 \pm 0.42 a$ & $5.8 \pm 0.70 b$ & 50.4 \\
\hline & $E D_{90}$ & $7.5 \pm 4.93 a$ & $10.4 \pm \quad 2.71 a$ & $52.2 \pm 10.66 b$ & \\
\hline \multicolumn{6}{|l|}{ ALS-inhibitors } \\
\hline \multirow[t]{2}{*}{ Foramsulfuron } & $\mathrm{ED}_{50}$ & & $0.37 a$ & $0.25 b$ & 60 \\
\hline & $\mathrm{ED}_{90}$ & & $0.97 a$ & $1.01 b$ & \\
\hline \multirow[t]{2}{*}{ Nicosulfuron } & $\mathrm{ED}_{50}$ & $1.4 \pm 0.58 a$ & $0.13 a$ & $4.6 \pm 0.31 b$ & 60 \\
\hline & $E D_{90}$ & $5.6 \pm 3.23 b$ & $2.5 \pm 0.37 a$ & $9.4 \pm 0.83 b$ & \\
\hline
\end{tabular}

No significant differences (based on computed selectivity indices and corresponding $p$-values) between figures with the same letter, comparison within herbicide only (Experiment 1). 
Provided no antagonism or decrease in crop selectivity is foreseen, tank mixtures of HPPD-inhibiting herbicides should be considered to avoid unacceptable Panicum control. Indeed, our results show that for Panicum species that were poorly suppressed by one of the HPPD-inhibitors, good control was obtained with other HPPD-inhibitors. These differential responses may be attributed to differences in foliar uptake. However, differential herbicide metabolism and/or differential sensitivity or activity of the HPPD enzyme cannot be completely ruled out. Moreover, the safeners isoxadifen-ethyl and cyprosulfamide, included in the formulation with tembotrione and with isoxaflutole, respectively, may have obscured potential interspecific differences in foliar uptake by a possible differential effect on herbicide detoxification in the plant. Further research on the fundamental biokinetics of herbicide metabolism and uptake of these HPPD-inhibitor herbicides in Panicum species is necessary to provide conclusive explanations for this differential herbicide sensitivity profile.

The abovementioned poor (sulcotrione and mesotrione) to moderate (topramezone) sensitivity of $P$. schinzii to some HPPD-inhibiting herbicides may partly explain the rapid expansion of $P$. schinzii into Flemish corn fields during the last two decades (Verloove 2001, Van Landuyt et al. 2006, Vanderhoeven et al. 2006). This is particularly true for the widely used sulcotrione, being the first triketone herbicide introduced in 1992 into the Belgian corn market. Sulcotrione was rapidly and widely adopted by corn growers due to its broad-spectrum weed control ability. Similar to sulcotrione, mesotrione and topramezone gradually became a standard herbicidal compound in many corn herbicide tank mix combinations since their introduction in 2003 and 2008, respectively.

Contrary to HPPD-inhibiting herbicides, small interspecific differences in sensitivity to ALS inhibiting herbicides were observed (Table 3). Panicum schinzii and P. dichotomi- florum were equally sensitive to nicosulfuron. Moreover, $P$. capillare, P. schinzii and $P$. dichotomiflorum were very sensitive to doses that were at least six-fold lower than maximum authorized field doses. So, the addition of nicosulfuron or foramsulfuron to POST tank mixes containing HPPD-inhibitors may potentially improve control of mixed Panicum populations in the field provided no incompatibility is foreseen. As shown by Schuster (2007) mesotrione antagonized several ALS-inhibiting herbicides by reducing the efficacy of controlling the panicoid grasses Setaria viridis (green foxtail) and Setaria pumila (yellow foxtail). In case of antagonism, nicosulfuron and foramsulfuron may be applied in sequence. By adding one of these ALS-inhibitors selective pressure exerted by some HPPD-inhibiting herbicides, particularly when applied repeatedly, might be lowered thus slowing down the build-up of less sensitive Panicum populations. The latter may further be reduced by adding persistent soil-acting grass herbicides (such as dimethenamid-P) to POST tank mixes, thus avoiding survival of late emerging Panicum seedlings which might be missed by abovementioned foliar-applied herbicides.

The relative contribution from soil activity to weed control resulting from post-emergence applications was important for isoxaflutole and to a varying degree also for sulcotrione, mesotrione and tembotrione but not for topramezone and the ALS-inhibitors nicosulfuron and foramsulfuron (Table 4). Compared to seedlings growing in charcoal-free pots, doses of isoxaflutole required to obtain a $90 \%$ reduction in Panicum biomass, were ten-fold higher for seedlings growing in charcoal-topped pots. In our small pot experiments with regular overhead irrigation, considerable soil activity would be expected. Presumably, contribution from soil activity in the field will largely depend on soil moisture content. For example, in moist soils $P$. capillare seedlings at the three leaves stage may be controlled by twoand six-fold lower doses of tembotrione and sulcotrione,

Table 4: $\mathrm{ED}_{90}$ responses with standard errors of $P$. dichotomiflorum, $P$. capillare and $P$. schinzii to post-emergence HPPD- and ALS-inhibitors. Herbicides were applied at the three to four leaves stage of plants growing in charcoal-topped pots(+charcoal) and in charcoal-free pots (-charcoal) (Experiment 1)

\begin{tabular}{|c|c|c|c|c|c|c|c|}
\hline \multirow{3}{*}{ Herbicide } & \multicolumn{2}{|c|}{ P. dichotomiflorum } & \multicolumn{2}{|c|}{ P. capillare } & \multicolumn{3}{|c|}{ P. schinzii } \\
\hline & -charcoal & +charcoal & -charcoal & +charcoal & -charcoal & \multicolumn{2}{|c|}{ +charcoal } \\
\hline & \multicolumn{7}{|c|}{ g ai ha-1 } \\
\hline \multicolumn{8}{|l|}{ HPPD-inhibitors } \\
\hline Isoxaflutole & - & - & $231 \pm 70.7 a$ & $1,256 \pm 660.2 b$ & $1,043 \pm 356.9 a$ & $94,996 \pm$ & ,705.7b \\
\hline Mesotrione & $49 \pm 17.1 a$ & $155 \pm 44.8 \mathrm{~b}$ & $382 \pm 188.9 a$ & $407 \pm 101.3 a$ & $459 \pm 156.9 a$ & $478 \pm$ & $155.7 a$ \\
\hline Sulcotrione & - & - & $278 \pm 115.4 a$ & $1,434 \pm 449.6 b$ & $884 \pm 236.0 a$ & $448 \pm$ & $85.7 a$ \\
\hline Tembotrione & $67 \pm 20.0 a$ & $46 \pm 3.3 a$ & $139 \pm 30.5 a$ & $247 \pm 39.3 b$ & $26 \pm 2.8 \mathrm{a}$ & $40 \pm$ & $4.5 b$ \\
\hline Topramezone & $34 \pm 6.7 a$ & $27 \pm 5.0 \mathrm{a}$ & $8 \pm 1.2 \mathrm{a}$ & $8 \pm 1.2 \mathrm{a}$ & $6 \pm 2.2 \mathrm{a}$ & $9 \pm$ & $2.0 \mathrm{a}$ \\
\hline \multicolumn{8}{|l|}{ ALS-inhibitors } \\
\hline Foramsulfuron & - & - & $1.5 \mathrm{a}$ & $1.1 \mathrm{a}$ & $1.4 \mathrm{a}$ & $10 \pm$ & $1.3 \mathrm{a}$ \\
\hline Nicosulfuron & $7 \pm 2.8 a$ & $10 \pm 1.5 a$ & $0.4 \mathrm{a}$ & $0.2 \mathrm{a}$ & $14 \pm 3.6 \mathrm{a}$ & $18 \pm$ & $4.3 a$ \\
\hline
\end{tabular}

No significant differences (based on computed selectivity indices and corresponding $p$-values) between figures with the same letter, comparison within herbicide/species combination only (Experiment 1). 
respectively, than in dry soils. This can be indirectly deduced from pot experiment 1 assuming soil activity in dry soils to be comparable with soil activity in charcoal-topped substrate and soil activity in moist soils to be comparable with soil activity in charcoal-free substrate. In general, contribution from soil activity of foliar applied $\beta$-triketones (mesotrione, sulcotrione and tembotrione) and isoxaflutole was more important for $P$. capillare than for $P$. dichotomiflorum and $P$. schinzii. This differential response may be attributed to interspecific differences in root pattern. Gross et al. (1992) found that most roots of 12-day-old P. capillare seedlings were close to the soil surface. This root pattern may favour root uptake of foliar-applied herbicides, thus increasing relative contribution from soil activity.

\section{Experiment 2}

Different locally naturalized $P$. dichotomiflorum populations showed a high variation in degree of sensitivity (based on $\mathrm{ED}_{90}$ doses) to HPPD-inhibiting herbicides mesotrione, sulcotrione and tembotrione but not to the highly effective herbicides topramezone and nicosulfuron (Table 5). ED90 doses of mesotrione, sulcotrione and tembotrione varied by a factor of up to 3 . This diverse response may reflect genetic variability among $P$. dichotomiflorum populations. Interspecific hybrids are not known. Indeed, $P$. dichotomiflorum being a hexaploid and $P$. capillare and $P$. schinzii being diploids, hybridization is not expected to occur spontaneously. The high degree of intraspecific variability in herbicide sensitivity may be rather surprising for a species that only recently (beginning of the $1990 \mathrm{~s}$ ) became a naturalized species in Flemish corn fields. Most likely, new populations with a different genetic background are continuously introduced in Flemish corn fields as casual grain aliens, thus increasing genetic variability among populations. In Belgium, seeds of $P$. dichotomiflorum are found in grain elevators in port areas as contaminant seeds of imported grain seeds (Verloove 2001). Nowadays, many P. dichotomiflorum populations are found as ephemeral populations in port areas, near grain stores, by roads or railway tracks, on dumps etc.. From these habitats they can gradually spread and naturalize in corn fields (Verloove 2001). According to Freckmann \& Lelong (2003) P. dichotomiflorum exhibits substantial phenotypic variation in North-America. Spikelet length and form can range from less than $3 \mathrm{~mm}$ to nearly $4 \mathrm{~mm}$ and from shortly acuminate to subobtuse. In habit prostrate, ascending as well as erect plants can be observed.

Furthermore, ranking of populations according to the degree of sensitivity (based on $\mathrm{ED}_{90}$ doses) depended on HPPD-inhibitor applied (Table 5). Populations 'Adegem' and 'Damme' were significantly less sensitive to mesotrione than population 'Ursel'. Compared to other $P$. dichotomiflorum populations tested, population 'Bellem' required a twoto three-fold lower dose of tembotrione to achieve $90 \%$ reduction in biomass. Population 'Bellem' was also significantly more sensitive to sulcotrione than 'Adegem'. Contrary to mesotrion, sulcotrione and tembotrione, no significant intraspecific differences in $\mathrm{ED}_{90}$ response were found for topramezone and nicosulfuron. Except for tembotrione, all $P$. dichotomiflorum populations were controlled by doses lower than authorized in the field. The $P$. dichotomiflorum populations 'Adegem' and 'Lembeke' required the maximum authorized field dose to achieve $90 \%$ reduction in biomass.

Despite being rather small compared to interspecific variation in herbicide sensitivity, intraspecific variation in herbicide sensitivity may further complicate the appropriate choice of HPPD-inhibiting herbicides and doses as well. Low dose applications may increase the risk of unsatisfactory control of some $P$. dichotomiflorum populations. This is particularly true for mesotrione, sulcotrione and tembotrione for which $\mathrm{ED}_{90}$ doses vary substantially among populations. Similar to abovementioned interspecific differences in sensitivity, these intraspecific differential responses may be attributed to differences in foliar uptake, differential herbi-

Table 5: $\mathrm{ED}_{90}$ responses with standard errors of geographically distinct $P$. dichotomiflorum populations to foliar-applied HPPD-inhibitors (mesotrione, sulcotrione, tembotrione and topramezone) and nicosulfuron (Experiment 2) applied at the three true leaves stage

\begin{tabular}{|c|c|c|c|c|c|}
\hline \multirow{3}{*}{ Herbicide } & \multicolumn{5}{|c|}{ P. dichotomiflorum population } \\
\hline & \multirow[t]{2}{*}{ Adegem } & \multirow[t]{2}{*}{ Bellem } & \multirow{2}{*}{$\frac{\text { Damme }}{\text { g ai ha-1 }}$} & \multirow[t]{2}{*}{ Lembeke } & \multirow[t]{2}{*}{ Ursel } \\
\hline & & & & & \\
\hline \multicolumn{6}{|l|}{ HPPD-inhibitors } \\
\hline Mesotrione & $68.9 \pm 13.10 a$ & $57.3 \pm 10.44 a b$ & $79.0 \pm 18.23 a$ & $55.8 \pm 9.54 a b$ & $36.8 \pm 9.03 b$ \\
\hline Sulcotrione & $186.4 \pm 31.83 a$ & $105.7 \pm 15.74 b$ & $177.6 \pm 43.20 a b$ & $133.1 \pm 23.92 a b$ & \\
\hline Tembotrione & $101.4 \pm 24.88 \mathrm{a}$ & $38.6 \pm 7.29 b$ & $75.1 \pm 19.10 \mathrm{a}$ & $105.9 \pm 28.23 a$ & $57.7 \pm 21.53 a b$ \\
\hline Topramezone & $10.0 \pm 1.24 a$ & $10.0 \pm 2.19 a$ & $3.6 \pm 2.97 a$ & $9.2 \pm 2.76 a$ & $11.3 \pm 3.26 \mathrm{a}$ \\
\hline \multicolumn{6}{|l|}{ ALS-inhibitor } \\
\hline Nicosulfuron & $7.6 \pm 1.50 \mathrm{a}$ & $5.2 \pm 1.26 a$ & $6.6 \pm 1.35 a$ & $9.2 \pm 2.75 a$ & \\
\hline
\end{tabular}

No significant differences (based on computed selectivity indices and corresponding p-values) between figures with the same letter, comparison within herbicide only (Experiment 2). 
cide metabolism and/or differential sensitivity or activity of the HPPD enzyme.

\section{Experiment 3}

The $\mathrm{ED}_{90}$ response (expressed absolute in Table 6 or relative to $\mathrm{ED}_{90}$ dose for $P$ capillare plants treated at the one leaf stage in Fig. 1 and 2) of $P$. capillare, $P$. dichotomiflorum and $P$. schinzii to foliar-applied topramezone and nicosulfuron was largely dependent on growth stage. Topramezone sensitivity of $P$. schinzii and $P$. dichotomiflorum, and of $P$. capillare respectively decreased exponentially and linearly with seedling age (Fig. 1). Topramezone sensitivity dropped drastically beyond the two true leaves stage for $P$. schinzii and the three true leaves stage for $P$. dichotomiflorum. At the four true leaves stage, $\mathrm{ED}_{90}$ doses were two- to eleven-fold higher than at the one leaf and two true leaves stage, irrespective of Panicum species (Table 6). Amongst Panicum species, $P$. schinzii was least sensitive to topramezone, irrespective of leaf stage. At the two and three leaves stages, $P$. dichotomiflorum required lower $\mathrm{ED}_{90}$ doses than $P$. capillare seedlings.

Nicosulfuron sensitivity of $P$. schinzii and $P$. capillare linearly decreased with increasing number of true leaves (Fig. 2). Contrary to P. capillare and $P$ schinzii, P. dichotomiflorum showed highest sensitivity at the two true leaves stage (Table 6). However, beyond the two leaves stage, sensitivity was lowered again. Panicum capillare plants were

Table 6: $\mathrm{ED}_{50}$ and $\mathrm{ED}_{90}$ responses with standard errors of $P$. dichotomiflorum, $P$. capillare and $P$. schinzii to foliar-applied topramezone and nicosulfuron as influenced by growth stage (Experiment 3)

\begin{tabular}{|c|c|c|c|c|c|}
\hline \multirow[t]{3}{*}{ Species } & \multirow{3}{*}{$\begin{array}{l}\text { Growth } \\
\text { stage† }\end{array}$} & \multicolumn{2}{|c|}{ Topramezone } & \multicolumn{2}{|c|}{ Nicosulfuron } \\
\hline & & $\mathrm{ED}_{50}$ & $\mathrm{ED}_{90}$ & $\mathrm{ED}_{50}$ & $E D_{90}$ \\
\hline & & \multicolumn{4}{|c|}{ g ai ha-1 } \\
\hline \multirow[t]{4}{*}{ P. dichotomiflorum } & $\mathrm{BBCH} 11$ & $0.8 \pm 1.17 a$ & $3.3 \pm 4.26 a$ & $0.3 \pm 3.39 a$ & $11.7 \pm 81.64 a b$ \\
\hline & $\mathrm{BBCH} 12$ & $1.5 \pm 0.43 a$ & $4.6 \pm 2.80 a$ & $3.3 \pm 0.86 b$ & $5.3 \pm 2.55 a$ \\
\hline & $\mathrm{BBCH} 13$ & $2.9 \pm 0.34 a$ & $7.2 \pm 1.63 a$ & $5.3 \pm 0.83 b c$ & $11.4 \pm 3.52 b$ \\
\hline & $\mathrm{BBCH} 14$ & $11.5 \pm 2.01 b$ & $37.5 \pm 15.45 b$ & $7.5 \pm 1.39 c$ & $22.6 \pm 11.66 b$ \\
\hline \multirow[t]{4}{*}{ P. capillare } & $\mathrm{BBCH} 11$ & $1.1 \pm 0.51 a$ & $2.6 \pm 1.42 \mathrm{a}$ & $0.3 \pm 0.26 a$ & $1.0 \pm 0.47 a$ \\
\hline & $\mathrm{BBCH} 12$ & $1.3 \pm 0.36 a$ & $7.8 \pm 3.56 b$ & $0.6 \pm 0.11 b$ & $1.5 \pm 0.51 a$ \\
\hline & $\mathrm{BBCH} 13$ & $2.1 \pm 0.48 \mathrm{a}$ & $16.0 \pm 8.08 \mathrm{bc}$ & $0.9 \pm 0.09 c$ & $1.7 \pm \quad 0.37 a$ \\
\hline & $\mathrm{BBCH} 14$ & $5.0 \pm 0.60 b$ & $20.6 \pm 5.38 c$ & $1.3 \pm 0.10 \mathrm{~d}$ & $4.8 \pm 0.73 b$ \\
\hline \multirow[t]{4}{*}{ P. schinzii } & $\mathrm{BBCH} 11$ & $1.7 \pm 0.40 \mathrm{a}$ & $5.9 \pm 2.80 a$ & $1.8 \pm 0.33 a$ & $6.2 \pm 2.09 a$ \\
\hline & $\mathrm{BBCH} 12$ & $7.7 \pm 0.71 \mathrm{ab}$ & $11.5 \pm 2.27 a$ & $4.5 \pm 0.73 b$ & $11.4 \pm \quad 3.77 a b$ \\
\hline & $\mathrm{BBCH} 13$ & $9.7 \pm 1.44 b$ & $35.0 \pm 10.68 b$ & $6.2 \pm 0.71 b$ & $13.0 \pm 3.52 \mathrm{ab}$ \\
\hline & BBCH 14 & $13.0 \pm 3.44 b$ & $61.0 \pm 85.40 b$ & $6.5 \pm 1.07 b$ & $24.9 \pm 10.55 b$ \\
\hline
\end{tabular}

$\dagger \mathrm{BBCH}$ 11, one true leaf; $\mathrm{BBCH}$ 12, two true leaves, $\mathrm{BBCH}$ 13, three true leaves; $\mathrm{BBCH}$ 14, four true leaves. No significant differences (based on computed selectivity indices and corresponding $p$-values) between figures with the same letter, comparison within herbicide and effective dose only (Experiment 3).

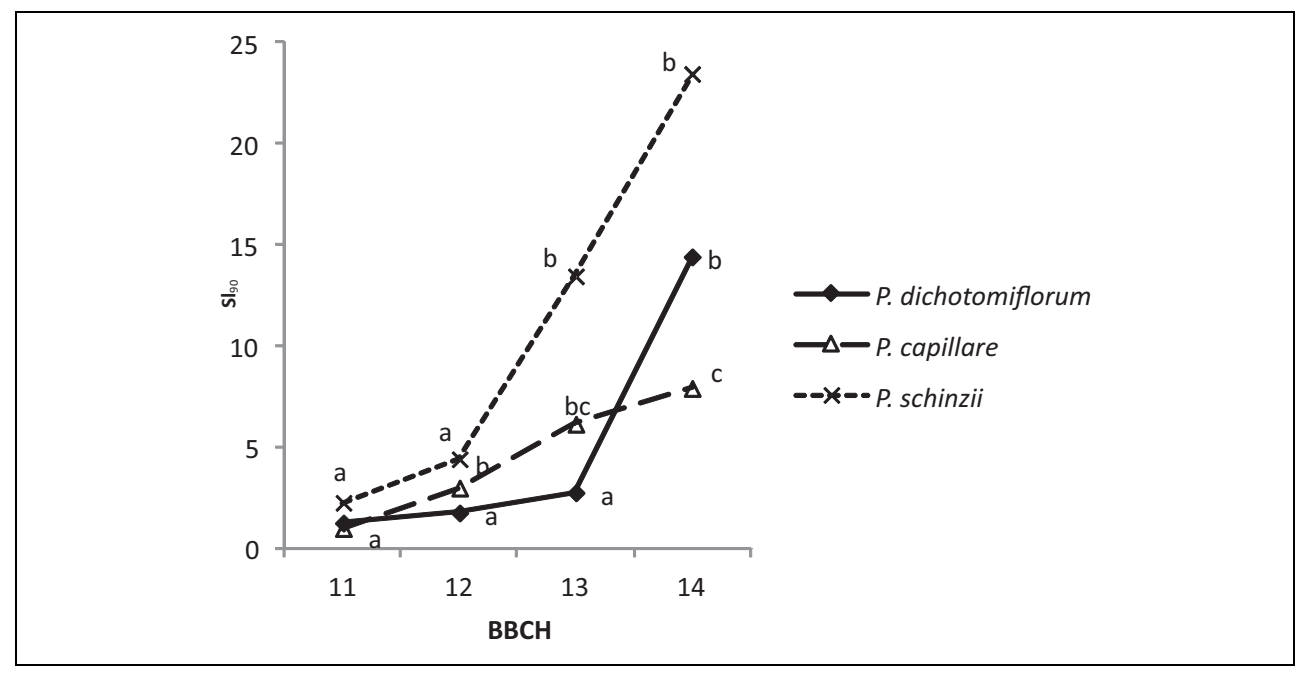

Fig. 1: The performance of topramezone for $P$. capillare, $P$. dichotomiflorum and P. schinzii as influenced by growth stage (Experiment 3). The performance is expressed as a $\mathrm{SI}_{90}$ index. i.e. $\mathrm{ED}_{90}$ dose relative to $E D_{90}$ response for first leaf stage plants of $P$. capillare (i.e. $2.6 \mathrm{~g}$ ai ha-1 topramezone). No significant differences (based on computed selectivity indices and corresponding $p$-values) between data points with the same letter; comparison within species only. 


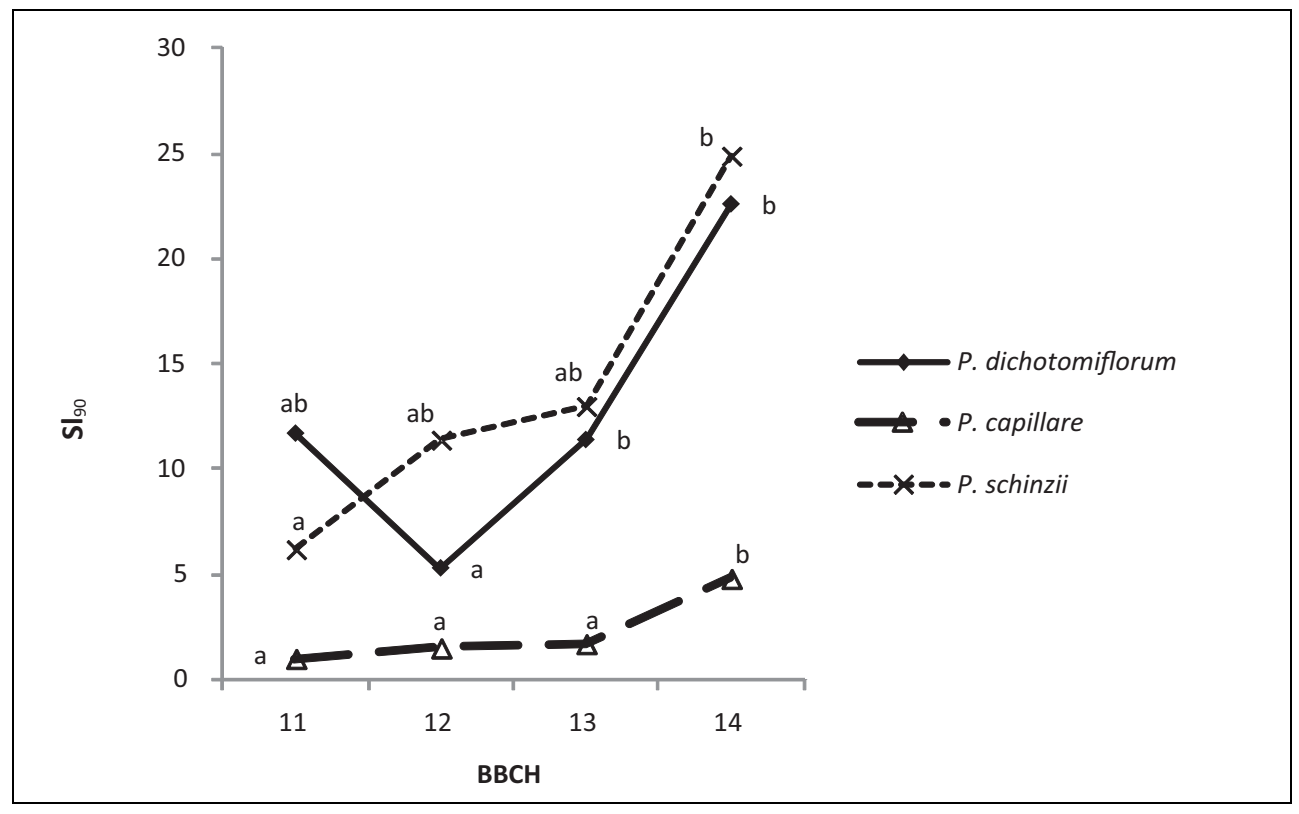

Fig. 2: The performance of nicosulfuron for $P$. capillare, $P$. dichotomiflorum and P. schinzii as influenced by growth stage (Experiment 3). The performance is expressed as a $\mathrm{Sl}_{90}$ index. i.e. $\mathrm{ED}_{90}$ dose relative to $\mathrm{ED}_{90}$ response for first leaf stage plants of $P$. capillare (i.e. $1.0 \mathrm{~g}$ ai ha $\mathrm{ha}^{-1}$ nicosulfuron). No significant differences (based on computed selectivity indices and corresponding $p$-values) between data points with the same letter; comparison within species only. significantly less sensitive to nicosulfuron when treated at the four true leaves stage than at all other leaf stages. Four leaves stage plants of $P$. schinzii were four-fold less sensitive than plants at the one leaf stage. Panicum dichotomiflorum sensitivity was four-fold lower at the four true leaves stage than at the two true leaves stage. Amongst Panicum species, nicosulfuron sensitivity was lowest for $P$. schinzii (except for one leaf stage seedlings) and highest for $P$. capillare, irrespective of leaf stage.

The reduced sensitivity with seedling age can be explained by a lower penetration, since herbicide penetration is hampered as plants age owing to the development of a thicker cuticle or altered cuticle composition (Aldrich \& Kremer 1997). Moreover, herbicide metabolism may be higher as plants age as shown by Singh \& Singh (2004) for glyphosate and trifloxysulfuron.

Overall, results of these experiments indicate that difficulties may arise in the successful chemical control of Panicum grasses due to interspecific differences in herbicide sensitivity in particular for HPPD-inhibiting herbicides. Compared to $P$. dichotomiflorum, satisfactory POST control of $P$. schinzii has required seven-to eight-fold higher doses of topramezone and mesotrione in the conducted pot experiments. Hence, correct identification of Panicum species before treatment or foreknowledge about the composition of Panicum species present is a prerequisite to avoid insufficient Panicum control. Foreknowledge can be obtained by studying flower parts of surviving Panicum plants in the fall which enables correct identification. In addition, successful control of $P$. capillare, $P$. dichotomiflorum and $P$. schinzii largely depended on growth stage at the time of herbicide application. Sensitivity of Panicum seedlings to topramezone and nicosulfuron linearly or exponentially decreased with increasing number of true leaves at the time of herbicide application: at the four leaves stage, sensitivity was two- to eleven-fold lower than at the one leaf stage. Poor control by topramezone and nicosulfuron in the field can be expected in circum- stances where $P$. dichotomiflorum and $P$. schinzii seedlings in particular are developed beyond the three true leaves stage.

\section{References}

Aldrich RJ \& Kremer RJ, 1997. Principles in weed management. 2nd ed. Ames, Iowa State University Press.

Baker FWG \& Terry PJ, 1991. Tropical grassy weeds. CAB International. Melksham, UK, Redwood Press Limited.

Benson JM, 1982. Weeds in Tropical Crops: Review of Abstracts on Constraints in Production Caused by Weeds in Maize, Rice, Sorghum-Millet, Groundnuts, and Cassava, 1952-1980. Rome, Italy: FAO Plant Protection and Protection Paper no. 32, supp. 1.

Bulcke R, Cools K, Callens D \& Eelen H, 1996. Response of selected crops and weeds to soil-applied sulcotrione. Med Fac Landb Toeg Biol Wet Univ Gent 61:1049-1054.

Clements DR, DiTommaso A, Darbyshire SJ, Cavers PB \& Sartonov AD, 2004. The biology of Canadian weeds. 127. Panicum capillare L. Can J Plant Sci 84, 327-341.

Freckmann RW \& Lelong MG, 2003. Panicum L. In: Barkworth ME, Capels KM, Long S \& Piep MB (eds) 2003: Flora of North America North of Mexico. Volume 25. Oxford University Press, New York. 450-488.

Gibbs-Russell GEL, Watson L, Koekemoer M, Smook L, Barker NP, Anderson HM \& Dallwitz MJ, 1990. Grasses of Southern Africa: an Identification Manual with Keys, Descriptions, Classification and Automated Identification and Information Retrieval from Computerized Data. Pretoria: Botanical Research Institute, Memoirs of the Botanical Survey of South Africa No. 58.

Gross KL, Maruca D \& Pregitzer KS, 1992. Seedling growth and root morphology of plants with different life-histories. New Phytol 120, 535-542.

Hoste I \& Verloove F, 2001. De opgang van $\mathrm{C}_{4}$ grassen (Poaceae, Paniceae) in de snel evoluerende onkruidvegetaties 
in maïsakkers tussen Brugge en Gent (Vlaanderen, België). Dumortiera 78, 2-11.

Knezevic SZ, Streibig JC \& Rits C, 2007. Utilizing R software package for dose-response studies: the concept and data analysis. Weed Technol 21, 840-848.

R Development Core Team, 2010. R: A language and environment for statistical computing. R Foundation for Statistical Computing, Vienna, Austria. ISBN 3-900051-07-0, URL http://www.R-project.org.

Ritz C \& Streibig JC, 2005. Bioassay analysis using R. J Stat Softw 12, 1-12.

Rouchaud O, Neus O, Cools K \& Bulcke R, 2000. Dissipation of the triketone mesotrione herbicide in the soil of corn crops grown on different soil types. Toxicol Environ Chem 77, 31-40.

Santel HJ, 2009. Laudis ${ }^{\circledR}$ OD - a new herbicide for selective post-emergence weed control in corn (Zea mays L.). Bayer CropSci J 62, 95-108.

Schönhammer A, Freitag F \& Koch H, 2006. Topramezone ein neuer Herbizidwirkstoff zur hochselektiven Hirse- und Unkrautbekämpfung in Mais. J Plant Dis Protect, Suppl, 1023-1031.

Schulte W \& Köcher H, 2009. Tembotrione and combination partner isoxadifen-ethyl -mode of herbicidal action. Bayer CropSci J 62, 35-52.

Schuster C, 2007. Weed Science Education and Research: The Agronomy Learning Farm and Mesotrione and Sulfonylurea Herbicide Interactions. Ph.D dissertation. Manhattan, Kansas, Kansas State University.

Singh S \& Singh M, 2004. Effect of growth stage on trifloxysulfuron and glyphosate efficacy in twelve weed species of Citrus groves. Weed Technol 18, 1031-1036.
Soltani N, Kaastra AC, Swanton CJ \& Sikkema PH, 2012. Efficacy of topramezone and mesotrione for the control of annual grasses. Int Res J Agric Sci Soil Sci 2, 46-50.

Streibig JC, Rudemo M \& Jensen JE, 1993. Dose-response curves and statistical models. In: Streibig JC \& Kudsk P (eds) 1993: Herbicide Bioassays. CRC Press, Boca Raton. 29-55.

Vanderhoeven S, Pieret N, Tiebre MS, Dassonville N, Meerts P, Rossi E, Nijs I, Pairon M, Jacquemart AL, Vanhecke L, Hoste I, Verloove F \& Mahy G, 2006. Invasive Plants in Belgium: Patterns, Processes and Monitoring (Inplanbel). Brussels, Belgium: Belgian Science Policy, Final report.

Van Der Meijden R, 2005. Heukels' Flora of the Netherlands. Groningen, the Netherlands: Wolters-Noordhoff.

Van der Vaart AW, 1998. Asymptotic Statistics. Cambridge, UK, Cambridge University Press.

Van Landuyt W, Hoste I, Vanhecke L, Van Den Brempt P, Vercruysse W \& De Beer D, 2006. Atlas van de Flora van Vlaanderen en het Brussels Gewest. Instituut voor Natuuren Bosonderzoek, Nationale Plantentuin van België \& Flo. Wer., Belgium.

Vengris J \& Damon RA, 1976. Field growth of fall panicum and witchgrass. Weed Sci 24, 205-208.

Verloove F, 2001. A revision of the genus Panicum (Poaceae, Paniceae) in Belgium. Syst Geogr Pl 71, 53-72.

Wax LM, Fawcett RS \& Isely D, 1981. Weeds of the North Central States. Urbana-Champaign: University of Illinois, Agric. Exp. Stn, Bull. 772.

Wicks GA, Mahnken GW \& Hanson GE, 1995. Influence of small grain crops on weeds and ecofallow corn (Zea mays). Weed Sci 43, 128-133. 